Fóris Ágota

\title{
Fordítás és terminológia. Elmélet és gyakorlat
}

\author{
(Budapest: Károli Gáspár Református Egyetem - \\ L'Harmattann Kiadó, 2020. 211 pp. ISBN 978-963-414-743-5) \\ Veresné Valentinyi Klára \\ E-mail: veresne.valentinyi.klara@uni-mate.hu
}

Napjainkra megváltozott a fordítási környezet, de az nem változott, hogy a fordítás minőségének egyik legfontosabb mércéje a terminológia, amelyről a könyv valóban meggyőzi az olvasót. A monográfia öt nagy fejezetből áll: 1. A terminológiáról, 2. Fordítás és terminológia, 3. A terminológia mint a fordítóknak nyújtott információ- és tudásmenedzsment, 4. A terminológia szerepe a tudományos kommunikációban, 5. A skálafüggetlen hálómodell a fordításban. A jelen írás szerzőjének nehéz dolga van, hiszen a monográfia müfaját tekintve egy konkrét témában készült összefoglaló mü, amely már maga is értelemszerüen összefoglalás, tehát minden mondata egy fontos megállapítás vagy eredmény közlése az adott szakterületről. Ez a monográfia is ilyen, minden mondata és fejezete kikristályosodott, fontos megállapítás, amelyet szívünk szerint egy az egyben, változtatás nélkül idéznénk, de ami nyilvánvalóan nem lehet egy recenzió célja, bár néhol nem tudjuk ezt elkerülni.

Az első fejezetben (A terminológiáról) a terminológia környezetéröl, szemléletéről, annak diakrón változásáról, a terminológia alapfogalmairól, valamint a terminológiai iskolákról és irányzatokról kapunk áttekintést tömören, olvasmányos stílusban. A szerző kihangsúlyozza, hogy a terminológia interdiszciplináris terület, itt találkoznak az eltérő szemléletű, szakmai hátterü és látásmódú szakemberek, ezért nagyon színes a szakterület, amelyet fontosnak tart, mivel sokáig részproblémákkal küszködő, egymástól elszigetelt csoportokban folytak a kutatások, a fejlesztést és az alkalmazást szolgáló munkák. Az interdiszciplinaritás egyébként már a kezdeti „wüsteri” időket is jellemezte, amelyet a terminológia három évtizeddel ezelötti paradigmaváltása csak felerősített, köszönhetően a megváltozott technikai, gazdasági, tudományos és társadalmi környezet robbanásszerü fejlődésének. Ugyanakkor az óriási fejlődés, az új fogalmak megjelenése nehézségekkel is jár, például ,a gazdasági, hivatali életben és számos tudományágban problémát okoz a magyar nyelvü terminológia hiánya, megalapozatlansága, a számos szinonima

Hivatkozás: Veresné Valentinyi K. 2021. Fóris Ágota: Fordítás és terminológia. Elmélet és gyakorlat. Fordítástudomány 23. évf. 2. szám. 129-134.

DOI: https://doi.org/10.35924/fordtud.23.2.11 
együttélése, a pontos jelentések tisztázatlansága, a használt fogalmak alá-, fölé-, mellérendeltségi kapcsolatainak meghatározatlansága" (p. 13.). Ahhoz, hogy egy szaknyelv az adott szakmai kommunikációs területen jól használható legyen, az egyik legfontosabb feltétel az említett terminológiai jelenségeknek a kezelése, melynek eszközei a terminológiai tevékenység tervezése, a terminusok összegyüjtése, harmonizációja és nyilvánossá tétele, állapítja meg a szerző.

A terminológiai munkafolyamatok elvi megalapozására, a gyakorlati problémák megfogalmazására és megoldására Magyarországon pozitív hatást fejtett ki az a tény, hogy az 1970-es években a magyar szakegyetemeken (Miskolci Nehézipari Müszaki Egyetem, majd ELTE TTK, DATE, Gödöllői Agrártudományi Egyetem, KLTE TTK stb.) szakfordító csoportok alakultak, 1974-től megkezdődött az ún. ágazati szakfordítóképzés, ahol hangsúlyos volt a szaknyelvoktatás is. Európa több országában megjelent a terminológia mint diszciplína a felsőoktatásban (BA-, MA- vagy PhD-szinten), van, ahol a lexikográfiával, másutt a fordítással, nyelvpolitikával vagy a számítógépes nyelvészettel összekötve, valamint új, terminológiai munkával és kutatással foglalkozó kutatóintézetek alakultak. 1992-ben jelent meg Teresa Cabré deskriptív szemléletű monográfiája La Terminologia címmel, amely fontos mérföldkőnek tekinthető. A terminológia súlyának növekedését elősegítette az EU-nak a soknyelvüség megőrzésére törekvő politikája is. A nyelvpolitikai célok megvalósításának támogatására szervezett nagyméretủ kutatás keretében végzett nyugat-európai felmérés eredményeként ajánlásokat fogalmaztak meg a tagállamok számára, melyek többek között kiemelték a szótárellátás javításának és a szótárhasználati kompetenciák fejlesztésének fontosságát. A terminológiai munka és kutatás eszköztárában paradigmaváltást hoztak a modern technikai eszközök (számítógép, internet, multimédia stb.), melyek nemcsak könnyebb, gyorsabb munkát tettek lehetővé, hanem új elvek kialakítását és ezek alapján új munkamódszerek kidolgozását, amely folyamat azonban Magyarországon indokolatlanul nagy késéssel kezdődött. „Csak” 2005-ben alakult meg a Magyar Nyelv Terminológiai Tanácsa a terminológiafejlesztés munkálatainak koordinálására. A tudományok müvelöinek figyelme is e kérdések felé fordult, amit jól mutat az is, hogy több terminológiai témájú konferenciát, kerekasztal-beszélgetést is rendeztek. Fontos állomás, hogy 2011 és 2018 között terminológia mesterszak müködött a Károli Gáspár Református Egyetemen. A témában monográfiák, tanulmánykötetek, kézikönyvek jelentek meg, 2008 és 2013 között jelent meg a Magyar Terminológia, 2017-töl pedig a Magyar Jogi Nyelv címü folyóirat; az általánosabb témájú és/vagy régebb óta megjelenő nyelvészeti folyóiratok (pl. Alkalmazott Nyelvtudomány, Fordítástudomány, Magyar Nyelv, Magyar Nyelvőr, 2001-től jelenik meg a Magyar Orvosi Nyelv) pedig szintén megjelenési lehetőséget biztosítanak a terminológiai tárgyú tudományos közlemények számára; valamint megkezdődött az elsősorban fordítási célú terminológiai adatbázisok építése, mutatja be a terminológia fejlődését dióhéjban a szerző.

Ezután A terminológiai szemlélet és a terminológiai rendszer címü részben a szerző alapfogalmakat tárgyal, ilyenek a terminológiai munka lépései, a szabvá- 
nyosítás és a harmonizáció, az onomasziológiai és a szemasziológiai megközelítés közötti különbségek, a terminológia rendszerekben az alá-fölérendeltségi viszonyok (hiperonima, hiponima, kohiponima, szinonima), illetve a fordítás számára fontos terminológiai hiány.

A szerző ezt követően $A$ terminus és a terminológia részben definiálja a terminust, amelynek az egyes diszciplínákban számos, eltérő megnevezése lehet: speciális szakszó, specifikus szakszó stb. A szerző terminusdefiníciója pedig a következő: ,a terminus egy meghatározott tárgykörön belüli fogalmat jelölö lexéma, szám, jel, vagy ezek kombinációja, vagyis olyan morfológiailag heterogén összetételü elemeket nevezünk terminusnak, amelyek pragmatikailag hasonló funkciót töltenek be a szakmai kommunikációban” (p. 26), tehát ,a terminus nem az »alakjától« válik terminussá, hanem a tartalmától és a használati módjától" (p. 27). A szerző fontos megállapítása, hogy a fogalom definíciójának a célja nyelvfüggetlenné (is) tenni fogalmakat és fogalmi rendszereket, és ha a definíció minden egyes nyelvben érvényes, akkor a hozzárendelt szóalak csak „,puszta cédula”, amely a fogalom egyértelmü jelölésére szolgál. Sajnos azonban a helyzet nem ennyire ideális, sokszor a definíció, a szabványosítás sem küszöböli ki például a szinonimák használatát, írja a szerző. Ezután a szerző definiálja a nomenklatúra és a taxonómia fogalmát, majd néhány kapcsolódó fordítási nehézségre is felhívja a figyelmet, mint például a földrajzi nevek fordítása. A következő részben a terminológia, a terminológiatudomány és a terminológiamenedzsment hármasát járja körül a szerző, és definiálja a doménorientált, a szövegorientált és az eseti (ad hoc) terminológiai munka fogalmát. Igen hasznos a következő rész, amelyben a terminológiai irányzatokkal (nyelvi-kommunikációs, szociokognitív) és iskolákkal, valamint a keretalapú és ontoterminológiai fogalmakkal ismerteti meg az olvasót.

A tudományos és a szakmai dokumentáció címü fejezetben megtudjuk, hogy a szakmai dokumentációk, kutatások többnyire angol nyelven vagy eleve két nyelven (pl. PhD-disszertációk, cégek, fordítóirodák saját adatbázisa) készülnek, ez utóbbiak segítik a terminusok egységes kodifikációját és elterjesztését. Összefoglalásul a szerző felhívja a figyelmet, hogy a terminológiai kutatás és munka, amely egyaránt lehet deskriptív és preskriptiv, elsősorban és hagyományosan szinkrón szemléletü, a mai nyelv szókészletével és fogalmaival foglalkozik, de támaszkodik 
a diakrón kutatások eredményeire is; többnyire onomasziológiai megközelítésü (vagyis fogalomalapú); interdiszciplináris jellegü, azaz szoros kapcsolatban van például a nyelvészet különböző területeivel, a logikával és az információtudománynyal. A jól kidolgozott terminológiai rendszerek a tudásalapú társadalom hatalmas méretủ és sebességủ információáramlásában az iránytü szerepét töltik be, zárja le az első fejezetet a szerző.

A második fejezetben a fordítás és terminológia viszonya kerül tárgyalásra. A szerző hangsúlyozza, hogy az egységes terminológiahasználat a szövegkoherencia fontos eszköze, amelyben a fordítástámogató eszközök nagy segítséget jelentenek. Ugyanakkor a fordító és a terminológus másképpen viszonyul a terminusokhoz, más a terminus helye a fordítási és a terminológiai munkafolyamatban, más jellegü ismeretekre van szükségük. A legfőbb különbség, hogy a fordító szövegszinten, a fordítás gyakorlata mint kommunikációs folyamat által közelíti meg a terminust, ahol a terminus a szakmai üzenetátadásnak csak az egyik eszköze, míg a terminológus a (szakmai, fogalmi) doménben elfoglalt helye szerint teszi ezt. A fordítástudomány és a terminológiatudomány viszonya ezért aszimmetrikus, írja a szerző, mellyel kapcsolatban a kutatások három fö területen folynak: a terminushasználat, az adatbázisok használata és a terminológiai ismeretek oktatása, amelyekre vonatkozóan konkrét kutatásokat is olvashatunk a monográfiában. A könyvnek kimondottan értékes része ez, mivel itt a szerző a magyarországi terminológiai gyakorlatot és a legújabb magyarországi kutatásokat is felsorolja, amelyeket véleményünk szerint kötelező olvasmányként kellene oktatni a fordítóképző intézményekben.

A fordító számára különösen érdekes a Forditói kérdések: Miröl ismeri fel a forditó a terminusokat? rész. A szakirodalomban található nézőpontok, megközelítések, definíciók nem minden esetben segítenek a fordítónak akkor, amikor egy konkrét lexikai egységről kell eldöntenie, hogy az adott lexéma az adott doménen (tárgykörben) terminus-e. Ezt a kérdést a szerző szerint úgy is fel lehet tenni, hogy Honnan lehet tudni, hogy melyik nyelvi egységet lehet szabadon forditani, és melyik kötött? Klaudy klasszikus ,,puha/kemény részek” meghatározását tartja a szerző az egyik leghasználhatóbb kiindulási pontnak, melyet azzal egészít ki, hogy tulajdonképpen azok a „tartalmas szavak” a terminusok, amelyek egy szakterülethez kapcsolódóan nemzetközi, európai, nemzeti vagy intézményi szinten rögzített jelentéssel és szintén rögzített nyelvi jellel rendelkeznek. De ide tartoznak azok a terminusok is, amelyeket valamilyen szakma, szakértői közeg már elfogadott és használ, még akkor is, ha nem szerepelnek sem a hivatalos szabványokban, sem szótárakban vagy egyéb referenciaművekben. Ez egyfajta normatív megközelítés. Hangsúlyozni szükséges azonban, hogy a terminusok kontextusfüggők (más tárgykörben más az ekvivalens), valamint a köznyelvi szavak dinamikus változások miatt terminologizálódhatnak, ami nehezíti a terminusok felismerését. Gyakorlati használhatósága miatt kiemeljük a szerző következő megállapítását: „A fordító pedig valójában azt keresi (és gyakran azt nevezi terminusnak), ami az adott szakterületen, tárgykörben az általa ismerthez (pl. a köznyelvi jelentéshez) képest $v a$ - 
lami mást jelenthet, vagy amit a célnyelven - a köznyelvihez, illetve az általa ismerthez képest - másképp neveznek meg, illetve azokat a kifejezéseket, amelyeket kulcsszavaknak érzékel a fordítandó szövegben. (...) A terminust a jelentéséröl és az adott kommunikációban betöltött szerepéröl lehet felismerni; de a jelentés absztrakt fogalom, amely (legtöbbször) nem a fordítandó szövegben található meg, hanem az egyéni elmében és a közös szakmai tudásban" (p. 71). Éppen ezért a terminológusok szerint a terminusokat nem fordítani kell, hanem eredeti szakmai szövegekben kell őket megkeresni, és megfeleltetni egymásnak, írja a szerző a következő részben, amelyben néhány tipikus terminusfordítási problémáról is olvashatunk. Ilyen például az az eset, amikor még nincsen kialakult terminológia, mert új szakterületről van szó. Ebben az esetben a fordított, a szakemberek vagy in-country reviewerek által lektorált szövegeket használják fel a terminológusok a terminusok összegyüjtésére, vagy új (akár ügyfélspecifikus) terminusokat alkotnak, de elfogadott gyakorlat például a glosszáriumok fordítása. Ezután a következő részben arra a kérdésre kapunk választ, hogy Hol keressük a forrásnyelvi terminusok ekvivalensét?, illetve a szerző összefoglalja az ekvivalenciameghatározásokat a fordítástudományban, majd hangsúlyozza, hogy a fordítónak minden esetben követnie kell a terminológiai normát, nem használhat szinonimát, összevonást, kihagyást, jelentésbővítést vagy -szükítést, persze hangsúlyozni kell azt is, hogy más stratégiát használunk teljes ekvivalencia, részleges ekvivalencia vagy az ekvivalencia hiánya esetén. Ez utóbbi esetében három stratégia használható: a funkcionális ekvivalens (analóg fordítás/fogalom, behelyettesítés, modifikáció); a formális ekvivalens (nyelvi ekvivalens, tükörfordítás), honosító stratégia; és a deskriptív ekvivalens (tömör elnevezés helyett magyarázó leírás, ez is honosító stratégia). Ezután ismerteti a szerző a terminusalkotás módszereit és elveit, valamint bemutatja a terminológia helyét a fordítási projektben, a moduláris szerkezetü mikroszövegek készítését. A Forditásorientált terminográfia részben a szerzö a központi adatbázisokat, a CAT-eszközöket, korpuszok fajtáit, a mesteradatbázist (master termbase), a speciális dokumentumkezelő rendszereket a fordítási projektfolyamat kezelésére, az integrált fordítási környezetet mutatja be.

A következő fejezet a fordítóknak és terminológusoknak nyújtott információés tudásmenedzsment-szolgáltatásokról szól, történeti megközelítést alkalmazva (a terminológia mint diszciplína megjelenése a szabványosításban, a nemzetközi szervezetek és magyar tagszervezetek megjelenése). Ezután a szerző bemutatja a terminológia evolúcióját a terminológiai irányzatok (a wüsteri, a nyelvi-kommunikációs, a szociokulturális, az ontológiai alapú irányzatok) ismertetésével. A negyedik és ötödik fejezetek egy-egy esettanulmányt tartalmaznak a szerző fordítással kapcsolatos terminológiai vizsgálataiból: az egyikben - a tudományos kommunikáció területén maradva - a lézerek magyar nyelvü terminológiáját, illetve a kétnyelvű (angol-magyar) lézerterminológiai dokumentáció készítésének fordítási és terminológiai vonatkozásait ismerteti a szerző; a másikban Teresa Cabré ,ajtók elméletéből" kiindulva a fordítás modellezésének lehetőségét, ezen belül a fordítás skálafüggetlen hálómodelljéről olvashatunk. A skálafüggetlen hálószerke- 
zet lehetővé teszi a fordítási folyamat dinamikájának és a terminus mint terminológiai egység (terminological unit) vizsgálatát és a kapcsolódó fogalmi (kognitív), nyelvészeti és kommunikációs hálózatokon lejátszódó folyamatok összekapcsolt, egyidejü, vagy ha szükséges, térben és időben elválasztott tanulmányozását, a forrásnyelvi és célnyelvi ekvivalenciát biztosító faktorok feltárását.

Az olvasó egy terminológiai alapművet tart a kezében, amely tömör, ám mégis részletes és alapos áttekintést nyújt a terminológia történeti megjelenéséröl és evolúciójáról, valamint a szerepéről mind az egynyelvü, mind pedig a kétnyelvü kommunikációban, ezért akár egy féléves, bevezető terminológiakurzuson tankönyvként kiválóan használható, de a gyakorló fordító számára is hasznos olvasmány. 